\title{
Darwin's Philosophical Imperative and the Furor Theologicus
}

\section{U. Kutschera}

Published online: 18 September 2009

(C) Springer Science + Business Media, LLC 2009
Keywords Charles Darwin · Catholicism · Creationism · Intelligent design · Origin of species

\section{Introduction}

On February 11, one day before Charles Darwin's 200th birthday, The Times reported that the Catholic Church has admitted that the British naturalist was on the right track when he claimed that Man descended from apes. Under the headline "Vatican buries the hatchet with Charles Darwin" the reader was informed that, according to leading officials, Darwin's theory of evolution "was compatible with Christian faith, and could even be traced to St Augustine and St Thomas Aquinas." Moreover, the head of the Pontifical Council for Culture said that "what we mean by evolution is the world as created by God." However, in a subsequent "birthday-article" published on February 12, 2009 by domradio.de entitled "Vatican acknowledges the theory of evolution," officials in Rome complained that Darwin's theories have been misused ideologically by anti-religious people to promote an atheistic world view.

In this article I discuss the questions of why Darwin's manuscript entitled "An Abstract of an Essay on the Origin of Species and Varieties through Natural Selection" (Fig. 1), that was published in November 1859 under the title On the Origin of Species (Fig. 2), had never been formally condemned by the Roman Catholic Church, despite the fact that the author attacked and refuted the Bible-based "theory of independent acts of creations" on many pages of his monograph. In addition, I describe the origin and impact of the furor theologicus that erupted immediately after the publication of Darwin's book. Finally, I discuss the question whether or not evolutionary biology and Christian faith are in fact "two sides of the same coin," as claimed by the Catholic Church and some other Christian associations. 


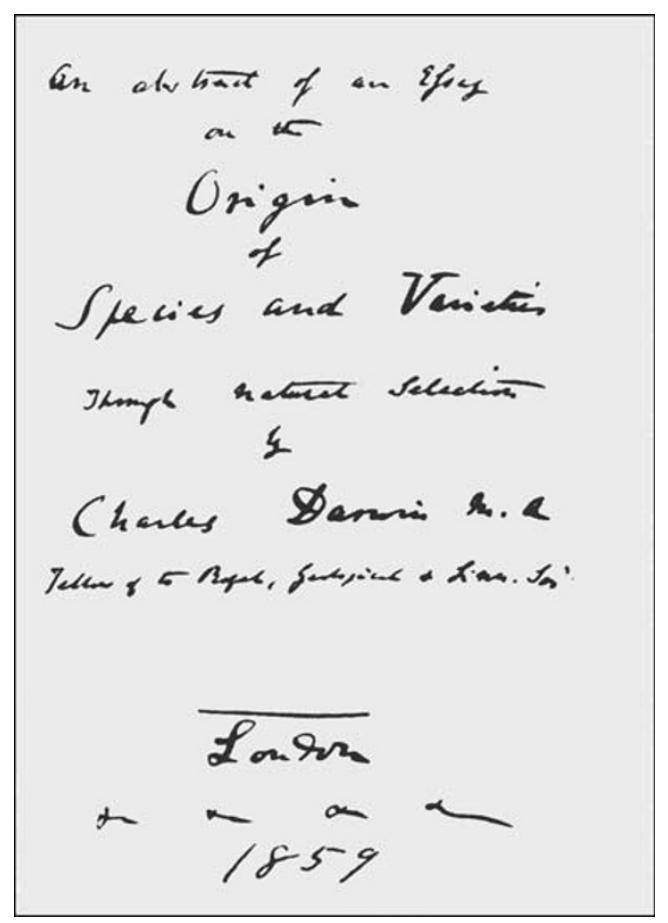

Fig. 1 Original, hand-written front page of Charles Darwin's manuscript that was published in November 1859 under the title On the Origin of Species by Means of Natural Selection. According to the publisher John Murray III, this new title was more appealing, since such a long manuscript was neither an "abstract" nor an "essay," and potential readers could not imagine what the author means by "natural selection"

\section{Natural Theology and the Intelligent Designer}

When Charles Darwin (1809-1882), a curiosity-driven, "born" naturalist, was a young man (Fig. 3), the direct interference of the Deity was, for most Victorians, the only imaginable explanation for the "origin" of all animals and plants on Earth. According to the then prevalent dogma of "natural theology," a detailed study of living beings (organisms) in nature would reveal the infinite creative powers of the Almighty, a supernatural entity also known as the "Intelligent Designer" (Numbers 2006; Ayala 2007).

The young Charles Darwin studied and admired the influential book of William Paley (1745-1805) entitled Natural Theology. In this monograph, the theologian presented his famous "argument from design" in the following words: "When we come to inspect the watch, we perceive ... that its several parts are framed and put together for a purpose, e.g. that they are formed and adjusted as to produce motion, and that motion so regulated as to point out the hour of the day...the inference, we think, is inevitable; that the watch must have a maker;... who comprehended its construction, and designed its use...Design must have a designer. That designer must have been a person. That person is God" (Paley 1803, p. 473). In other contexts, Paley (1803) used expressions such as "creative intelligence," "wisdom of the Deity," or "the Creator" to denote the "Intelligent Designer." For most scientists, the Bible and physical/living nature (stones, plants, animals etc.) were complementary "texts." This fact is illustrated in Fig. 4, where a theologian-naturalist is depicted in a landscape that reminds the viewer of the "Garden of Eden." In this picture, the "theo-biologist" says that he "intends to contemplate the natural world and the achievements of Jehova." Hence, natural science and Christian religion were not yet separated at that time.

As documented in detail elsewhere (Desmond and Moore 1991; Bowler 2003; Eldredge 2005, 2009a, b), Charles Darwin gradually lost his belief in the myths and tales written down in the Bible. In his Autobiography, Darwin mentioned that in 1836, "Whilst on board of the Beagle, I was quite orthodox, and I remember being heartily laughed
Fig. 2 Title page of the first edition of Charles Darwin's Origin of Species and a cartoon showing an ape reading this book, wherein the "human animal" is mentioned in only one sentence (adapted from the 1. Edn. of Darwin 1859 and a drawing published in the periodical Laborjournal)

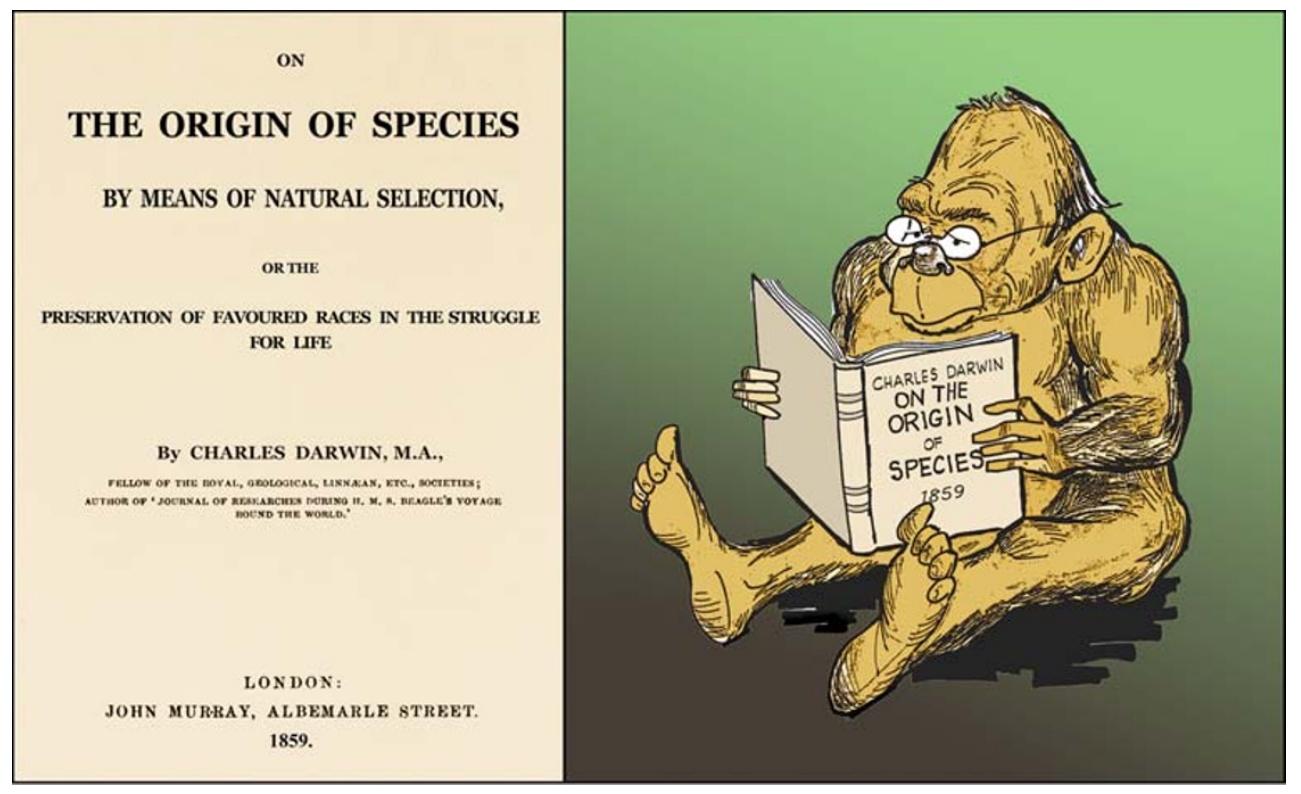




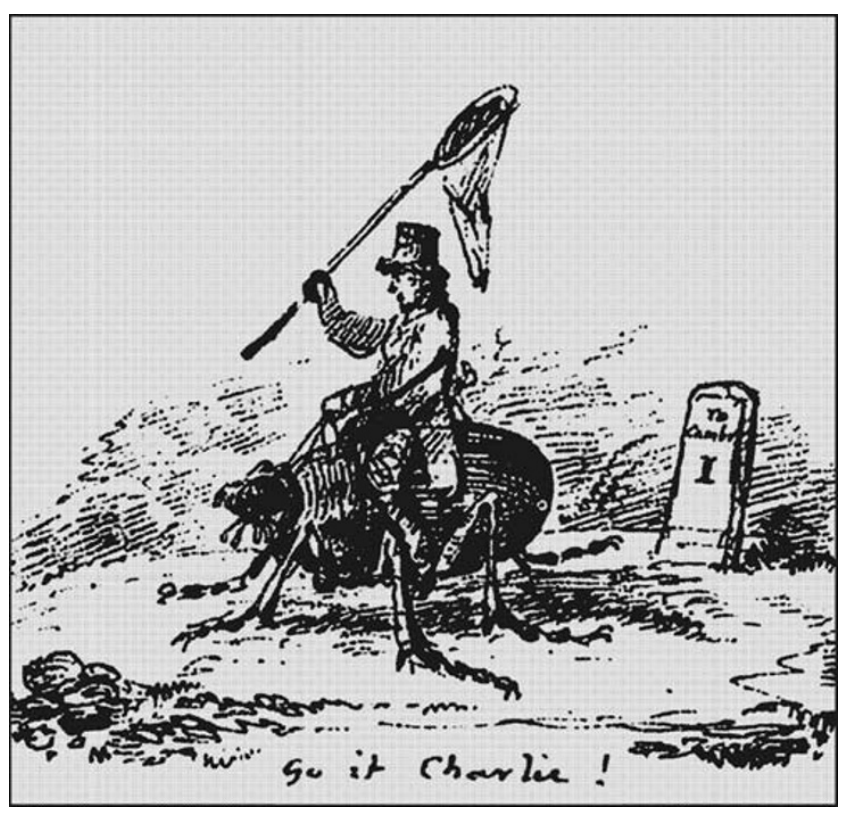

Fig. 3 The student Charles Darwin, ca. 1828, as a beetle hunter. Caricature of one of Darwin's friends with the remarks "Go it, Charly" and "To Cambridge"

at by several of the officers...for quoting the Bible as an unanswerable authority...But I had gradually come, by this time, to see that the Old Testament from its manifestly false history of the world..., and from its attributing to God the feelings of a revengeful tyrant, was no more to be trusted than the sacred books of the Hindoos, or the beliefs of any barbarian" (Barlow 1958, p. 85). Later, Darwin completely lost his faith in the Christian dogma of "intelligent design" (Fig. 5). The British naturalist wrote that "the old argument of design in nature, as given by Paley, which formerly seemed to me so conclusive, fails, now that the law of natural selection has been discovered" (Barlow 1958, p. 112). Despite Darwin's refutation, an evolved version of Paley's Intelligent Design argument re-emerged ca. 1990 in the United States and Europe (Kutschera 2005, 2006a, b) and has been promoted by a prominent member of the Catholic Church (Schönborn 2005). Eldredge (2001), Scott (2005), Kutschera (2005, 2006a, b), Numbers (2006), Coyne (2009) and others have shown that this "Neo-Paleyian" concept is nothing other than an unsupported religious dogma that has no place in any science curriculum.

\section{Darwin's Philosophical Imperative: The Separation of Scientific Facts from Biblical Dogmas}

Throughout his "species book" (Fig. 2), Darwin (1859, 1860, 1872a) attacked the Bible-based "theory of creation" in a variety of ways. The most explicit description of this naturalistic view can be found in the last section of the introduction, where he wrote that "I can entertain no doubt ..., that the view which most naturalists entertain, and which I formally entertained - namely, that each species has been independently created - is erroneous. I am fully convinced that species are not immutable; but ... are lineal descendants of some other and generally extinct species....Furthermore, I am convinced that Natural Selection has been the main, but not the exclusive means of modification" (Darwin 1859, p. 7). This key sentence was modified in the last (definitive) edition of the Origin of Species as follows: "Furthermore, I am convinced that Natural Selection has been the most important, but not the exclusive, means of modification" (Darwin 1872a, p. 22).

In the same year, Darwin published another, lesser-known book entitled The Expression of the Emotions in Man and Animals, wherein he again attacked the belief in the biblical story of Creation. After a brief description of the contributions of Herbert Spencer (1820-1903) and other writers, he wrote that "All the authors who have written on Expression, with the exception of Mr. Spencer-the great expounder of the principle of evolution - appear to have been firmly convinced that species, man of course included, came into existence in their present condition" (Darwin 1872b, p. 10).

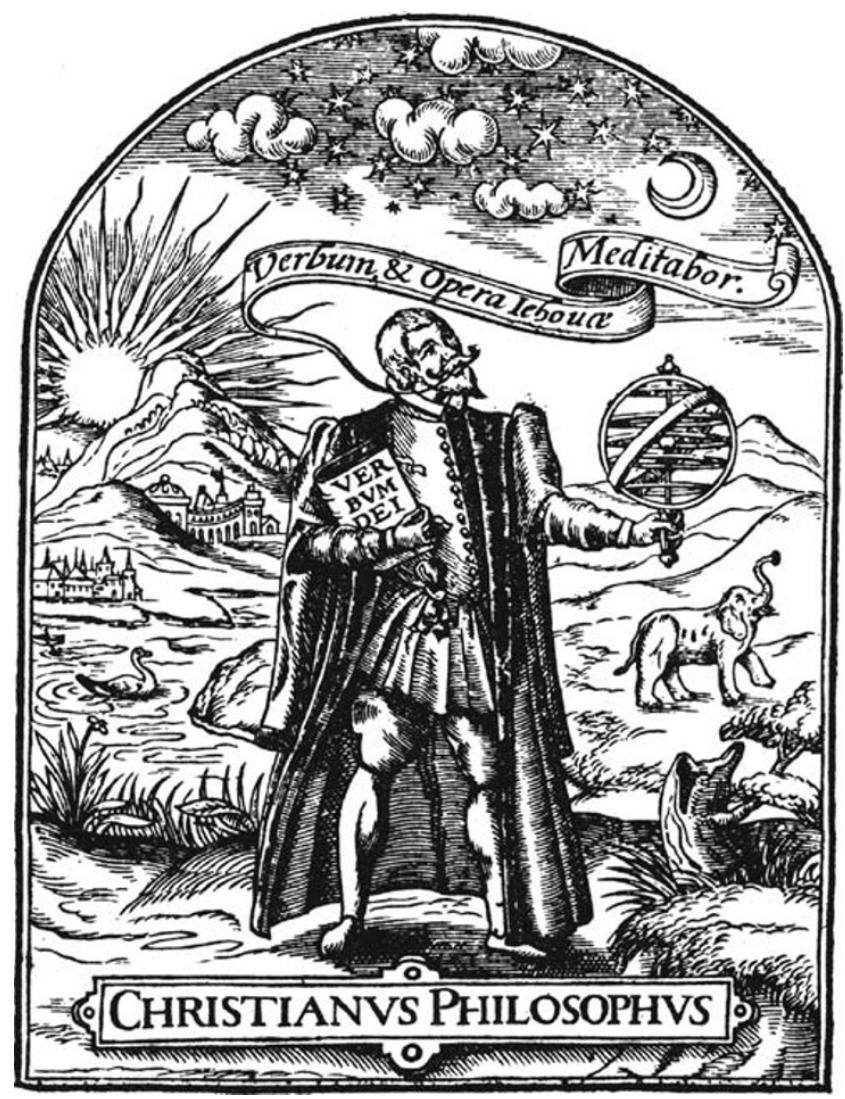

Fig. 4 A Christian naturalist, who studies the organisms (animals, plants) in nature and is inspired by the Bible. In these Holy Scriptures, the supernatural acts of the Creator are described (adapted from a woodcut, ca. 1600) 
Two pages later, he remarked that "No doubt as long as man and all other animals are viewed as independent creations, an effectual stop is put to our natural desire to investigate as far as possible the causes of Expression. By this doctrine, anything and everything can be equally well explained; and it has proved as pernicious with respect to Expression as to every other branch of natural history....He who admits on general grounds that the structure and habits of all animals have been gradually evolved, will look at the whole subject of Expression in a new and interesting light" (Darwin 1872b, p. 12). In these sentences, the British naturalist points out that the doctrine of independent acts of creations is pernicious (i.e., harmful) to man's desire to understand all aspects and processes that occur in the natural world. In other words, according to Darwin (1872b), creationism (inclusive of the argument from design) inhibits and may even prevent the progress of science (Fig. 5).

Darwin (1859, 1860, 1872a, b) was one of the first naturalists who strictly separated supernatural (religious) dogmas from empirical facts and their interpretations (theories). This proposed non-interference of belief systems vs. scientific facts and their naturalistic interpretations has been called "Darwin's philosophical imperative" (Kutschera 2008a). It should be mentioned that, only three years after the publication of the first edition of the Origin, Darwin

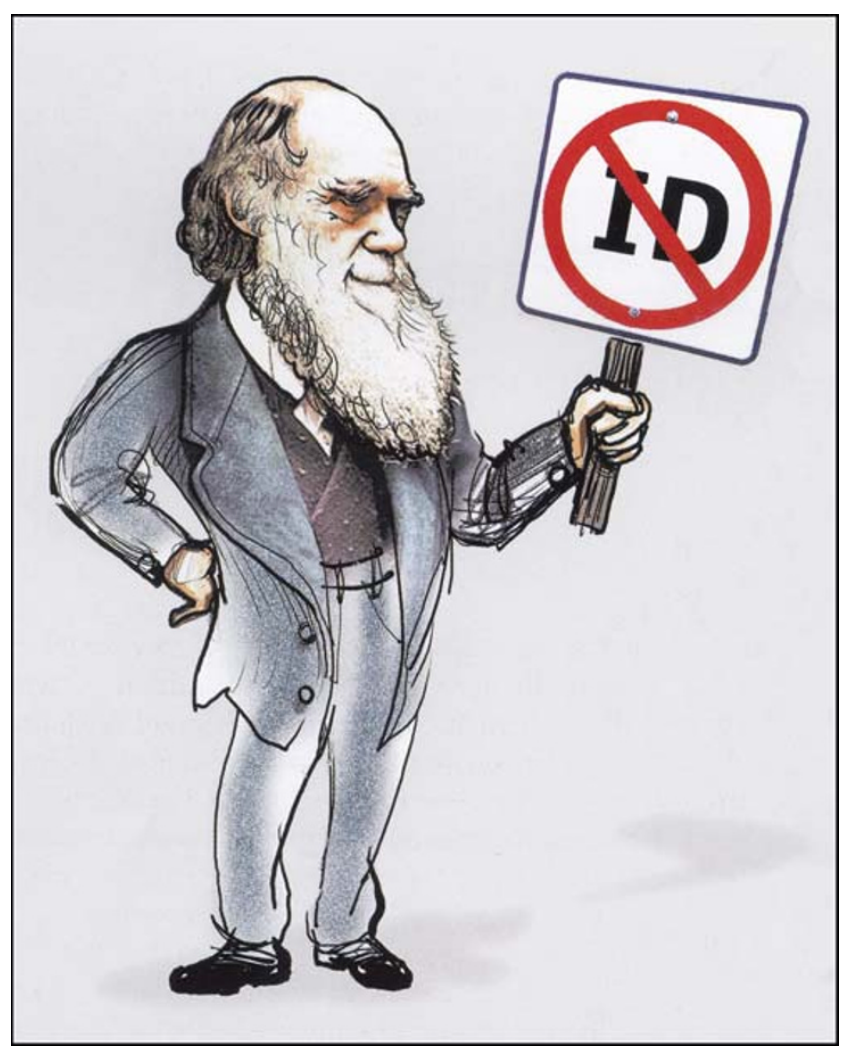

Fig. 5 Charles Darwin as an old man, refuting William Paley's "argument from design" (adapted from a caricature in the periodical Laborjournal) defended his naturalistic way of pursuing scientific research in a little-known book on the fertilisation of orchids by insects in the following words: "This treatise affords me also an opportunity of attempting to show that the study of organic beings may be as interesting to an observer who is fully convinced that the structure of each is due to secondary laws, as to one who views every trifling detail of structure as the result of the direct interposition of the Creator" (Darwin 1862 , p. 2). If we replace Darwin's old-fashioned word "secondary" by "natural (laws)," the basic message of this sentence becomes apparent (see below).

\section{The Eruption of the Furor Theologicus 150 Years Ago}

On November 19th 1859, only a few days before the first edition of Darwin's Origin of Species was published, an anonymous reviewer remarked that "Theologians will sayand they have a right to be heard - why construct another elaborate theory to exclude Deity from renewed acts of creation? Why not at once admit that new species were introduced by the creative energy of the Omnipotent?" (Peckham 1959). Although Charles Darwin was fully aware of the furor theologicus that would erupt in response to the publication of his "species book," he was disappointed that he could not convince this first reviewer of his novel naturalistic theory. On the other hand, John Murray III (1808-1892), who urged the author to publish his book under a more precise title (Figs. 1 and 2), must have been delighted-published statements like these and others ("If a monkey has become a man-what may not a man become?") aroused interest so that the trade sale scheduled for November 22 would be promoted. The printing of the first edition was 1,250 books, of which 1,192 copies were for sale. The book more than sold out; by November 26, 1859, not a single copy was left over, so that Darwin rapidly prepared a modified and corrected second edition that was published on December 26, 1859 (Darwin 1860).

One minor addition that appeared in the second and all subsequent editions of Darwin's Origin of Species (third ed., April 26, 1861; fourth ed., December 15, 1866; fifth ed., August 17, 1869 and sixth ed., February 19, 1872; see Peckham 1959) had far-reaching consequences that last to the present day: Darwin introduced a supernatural act "by the Creator" into his naturalistic "theory of descent with modification" (his synonym for "evolution"). In the first edition, Darwin wrote at the end of the text that "There is grandeur in this view of life, with its several powers, having been originally breathed into a few forms or into one; and that ..., from so simple a beginning endless forms most beautiful and most wonderful have been, and are being, evolved" (last sentence of the final chapter). In the second and all subsequent editions the author added a Bible-based 
wonder to the final sentence: "There is grandeur in this view of life, .... having been originally breathed by the Creator into a few forms or into one; and that ..., are being, evolved" (Darwin 1860; italics added).

All available historical evidence indicates that Darwin mentioned "the Creator" in the second and all subsequent editions to conciliate angry clerics. In a letter of March 29, 1863, Darwin wrote to Joseph Hooker (1817-1911) that "I have long regretted that I truckled to public opinion and used Pentateuchal term of creation, by which I really meant 'appeared by some wholly unknown process'-It is mere rubbish thinking, at present, of origin of life; one might as well think of origin of matter." Since most of the 1,192 copies of the first edition for sale had disappeared in the bookshelves of private customers, the 3,000 copies of the second edition (Darwin 1860) as well as the final version of the text (Darwin 1872a) became much better known than the original book of 1859. It is likely that the introduction of "the Creator" at the end of the text tamed the furor theologicus considerably, so that, after his death in 1882, the Anglican establishment of England claimed Charles Darwin, who had lost his religious faith entirely, as one of their own (Fig. 5). Moreover, the fact that Darwin's Origin of Species has never been placed on the Index Librorum Prohibitorum (1599 to 1962), a long list of books that were forbidden to read for orthodox Catholics, may be due to this Darwinian "theobiology." Finally, in February 2009, Pope Benedict XVI made the euphoric "Darwin-birthday-statements" quoted in the introduction of this Essay, claiming that Darwin's system of theories is compatible with Christian faith. However, what was Darwin's true opinion as to the origin of life on Earth? Was Darwin a Bible-based creationist, as the German palaeontologist Bronn (1860) and other scientists, who did not know the first edition of the Origin (Darwin 1859, without the Creator at the end of the text), suggested?

\section{Darwin's Theological Language, the Little Pond and the Age of the Earth}

Charles Darwin opens his "species book" of 1859 with two theological epigraphs by Whewell and Bacon that refer to the British way of reconciliation of science and religion. At that time, the laws discovered by naturalists were regarded as "secondary causes," whereas the biblical God, as the "Creator" of these natural laws, was considered the "primary cause." In the words of William Whewell (1794-1866), "events are brought about not by insulated interpositions of Divine power, exerted in each particular case, but by the establishment of general laws." In a second quote from Francis Bacon (1561-1626) it is stated that no man "can ... be too well studied in the book of God's word, or in the book of God's works...but rather let men endeavour an endless progress or proficience in both." This sentence implies that both the Holy Scriptures and nature have to be studied to understand the world as a whole (Fig. 4). The inclusion of these quotes may have been another Darwinian way of taming the expected furor theologicus.

More significant than these epigraphs, however, is the theological language Darwin used throughout his "species book." In the Bible, we find numerous statements such as "He who has the Son has life; he who does not have the Son of God does not have life" (1 John 5: 12). The biblical phrase "He who..." appears on many pages of the Origin, from the first to the last edition (Darwin 1859, 1860, 1872a), as if the author, a strict naturalist, would speak to a theologian who believes in special acts of independent creations (i.e., to Darwin himself when he was a young man, see Figs. 3 and 5). The Biblical "He who-phrase" also appears in other books of Darwin, such as in The Expression of the Emotions (Darwin 1872b; see the above quote).

According to Cosans (2005), Darwin's description of life being "breathed (by the Creator) into a few forms or into one" was a reference to Genesis 2:7 of the Old Testament, where the Biblical God breathes life into the nostrils of the first human, Adam. We do not know why Darwin (1859, 1860, 1872a) used these biblical phrases and expressionshis formal education as a theologian at Cambridge University may have been the cause, but it is also possible that he thought that by this means the text might become more attractive to his readers, most of whom were Christians. It is also conceivable that Darwin used these references to the Bible to please the theologians, but I consider this to be unlikely. At any rate, Darwin $(1859,1860,1872 a)$ described a scientific alternative to a Bible-based, Christian worldview, using in many sentences the language of a theologian.

Charles Darwin's famous hypothesis on the origin of the first cells is hidden in a letter to Joseph Hooker written on February first, 1871. Here, Darwin speculated that life could have emerged from "some warm little pond, with all sorts of ammonia and phosphoric salts, light, heat, electricity etc., present, so that a protein compound was chemically formed ready to undergo more complex changes." Moreover, in this letter, Darwin pointed out that "at the present day such matter would be instantly devoured or absorbed, which would not have been the case before living creatures were formed." In his seminal "warm little pond hypothesis," which marks the start of all rational "origin-oflife-speculations" (Hazen 2005), we find no trace of supernatural intervention: Darwin proposed an entirely naturalistic concept that decades later became a testable idea (laboratory experiments on prebiotic synthesis of organic molecules such as amino acids etc., see Hazen 2005).

Why did Charles Darwin not publish this hypothesis of 1871 in the last and definitive edition of his "species book" that appeared one year later in print? In Darwin (1872a) we 
read that life has been originally "breathed by the Creator into a few forms or into one"- a clear concession to the Bible-based, dogmatic world view of the theologians, who "have a right to be heard" (Peckham 1959). Hence, Darwin may have feared another eruption of the furor theologicus and therefore did not dare to include his new naturalistic hypothesis on the origin of life into the final (definitive) 1872 edition of the Origin of Species. This book was reprinted many times and soon became the standard edition of Darwin's masterpiece.

However, in this context it must be stressed that Darwin (1859, 1860, 1872a) did not mention the then popular "Biblical age of the Earth" of about 6,000 years. This young age was entirely unacceptable to Darwin the geologist (Eldredge 2009a, b), who restricted his discussion to the age estimations of William Thompson (1824-1907). This famous physicist ("Lord Kelvin") had calculated that the Earth is several (20 to 400) million years old (Burchfield 1975). The biologist-geologist Darwin was fully aware of the fact that Thompson's age calculations that he cited in his "species book" were not large enough to permit the gradual evolutionary development of all forms of life on Earth, which commenced with hypothetical primordial cells that must have existed prior to the Cambrium.

This "Darwinian dilemma" was solved in 1905 after the discovery of radioactivity and the suggestion of corresponding physical techniques (i.e. the use of radioactivity as a geological time-keeper). The true age of our blue planet (ca. 4,527 million years) was determined for the first time in the 1950s, based on the measurement of isotopic ratios by use of mass spectrometers (the "time machines" of the geochronologists). In the meantime, this value has been corroborated so many times by use of a variety of geochronological methods that the age of the Earth is now a well-established "fact of nature," and no longer "only a theoretical estimation of some evolutionists" (Dalrymple 2004).

\section{Catholicism and Evolutionary Biology—Two Sides of the Same Coin?}

At a Vatican Science Conference in November 2008, a central tenet of the Catholic Church was summarized as follows: "There is a belief in a creator who existed before the big bang and set the universe in motion." This religious dogma serves Pope Benedict XVI as spiritual basis in his fight against "evolutionism," a word coined by conservative Catholics as a modern synonym for "Darwinism." According to the "the-ists" Benedict XVI and the Vienna archbishop Christian Schönborn, these "isms" are used by non-believers for the promotion of "a-the-ism" via evolutionary biology (Schönborn 2005). This terminology and the corresponding accusations are unacceptable for the following reasons.
First, the attempt to depict evolution, labelled as "Darwinism," as though it were a political or religious ideology, i.e., the vision of a single individual or a sect (like "Marxism," "Leninism," "Catholicism," or "Protestantism") is a misrepresentation of the way scientists work and think. Evolutionary biology is a non-dogmatic system of modifiable theories that is based exclusively on empirical facts and data (Kutschera and Niklas 2004; Kutschera 2008a, b, 2009; Scott and Branch 2009; Coyne 2009) (Fig. 6).

Second, there are dogmatic faith systems that deserve the "ism" at the end, such as "Creationism," which is rejected by modern Catholics, due to their non-literal interpretation of the Bible (Numbers 2006). On the other hand, "Catholicism," the body of Catholic faith, includes, for instance, the belief that during the Holy Communion Jesus Christ is really, and not only metaphorically, present in

\section{EVOLUTION

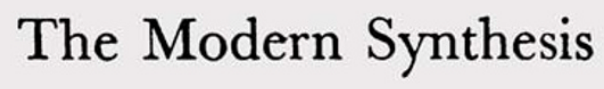

by

JULIAN HUXLEY, M.A., D.sC., F.R.s.

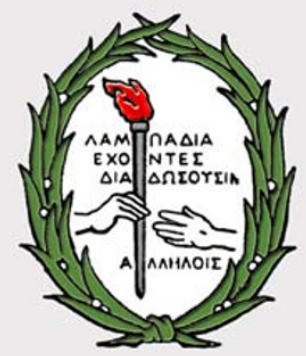

Harper \& Brothers Publishers New York and London, 1942

Fig. 6 Evolutionary biology is an interdisciplinary scientific discipline that originated in the 1940s in the United States of America with the publication of this and related monographs. It consists of an open system of theories from the geological and biological sciences (adapted from the title page of Julian Huxley's book of 1942 wherein the term "evolutionary biology" was introduced) 
what was previously bread and wine. This Catholic dogma has, as all the others, no empirical basis but rests on the blind belief in Biblical revelations and wonders.

Third, throughout his book On the Origin of Species, the geologist-biologist and theologian Charles Darwin distinguished between facts and their logical interpretation (i.e., theories) versus religious dogmas, such as the acts of a supernatural Creator. Although he included the phrase "by the Creator" in later editions of the text to tame the furor theologicus, this was not Darwin's honest way of doing science, as described in his private (unpublished) correspondence (see Seward 1909).

\section{Conclusions}

In October 1996, scientists around the world were pleased to read that Pope John Paul II acknowledged the accumulated scientific evidence that "evolution is more than just a hypothesis" (Abbott 1996). I think that the time is ripe for the Catholic Church and other Christian associations to accept, in addition to the fact of evolution, "Darwin's philosophical imperative" as detailed in his "species book." According to Darwin (1859, 1860, 1872a, b), science should not be mixed up or confused with religious dogmas and myths: what the British naturalist and most other biologists that followed him mean by naturalistic evolution is not identical with the mythical world as created via Biblical miracles. This Darwinian separation of documented facts from the belief in supernatural entities was the "big bang" for biology, which, in the wake of Darwin's unifying principle of descent with modification, evolved from an "art of collecting and classifying beetles" (Fig. 3) into the science of the twenty-first century.

Acknowledgements I thank Dr. Niles Eldredge for inviting me to contribute this Essay and the Alexander von Humboldt-Stiftung (Bonn, Germany) for financial support (AvH-fellowship 2009, Stanford, California, USA).

\section{References}

Abbott A. Papal confession: Darwin was right about evolution. Nature. 1996;383:753.

Ayala FJ. Darwin's greatest discovery: design without designer. Proc Natl Acad Sci USA. 2007;104:8567-73.

Barlow N, editor. The autobiography of Charles Darwin. London: Collins St. James's Place; 1958.

Bowler PJ. Evolution: the history of an idea. 3rd ed. Berkeley: The University of California Press; 2003.

Bronn HG. Schlusswort des Übersetzers. In: Charles Darwin, Über die Entstehung der Arten, übersetzt von HG Bronn nach der 2. Auflage. Stuttgart: E. Schweitzerbart'sche Verlagshandlung; 1860.
Burchfield JD. Lord Kelvin and the age of the Earth. New York: Science History; 1975.

Cosans C. Was Darwin a creationist? Persp Biol Med. 2005;48:32671.

Coyne JA. Why evolution is true. Oxford: Oxford University Press; 2009.

Dalrymple GB. Ancient Earth, ancient skies. The age of Earth and its cosmic surroundings. Stanford: Stanford University Press; 2004.

Darwin C. On the origin of species by means of natural selection, or the preservation of favoured races in the struggle for life. London: John Murray; 1859.

Darwin C. On the origin of species by means of natural selection, or the preservation of favoured races in the struggle for life. 2 nd ed. London: John Murray; 1860.

Darwin C. The various contrivances by which orchids are fertilised by insects. London: John Murray; 1862.

Darwin C. The origin of species by means of natural selection, or, the preservation of favoured races in the struggle for life. 6th ed. London: John Murray; 1872a.

Darwin C. The expression of the emotions in man and animals. London: John Murray; 1872b.

Desmond A, Moore J. Darwin. The life of a tormented evolutionist. New York: Warner Books; 1991.

Eldredge N. The triumph of evolution and the failure of creationism. San Francisco: Freeman; 2001.

Eldredge N. Darwin. Discovering the tree of life. New York: Norton; 2005.

Eldredge N. Experimenting with transmutation: Darwin, the Beagle, and evolution. Evo Edu Outreach. 2009a;2:35-54.

Eldredge N. A question of individuality: Charles Darwin, George Gaylord Simpson and transitional fossils. Evo Edu Outreach. 2009b;2:150-5.

Hazen RM. Genesis. The scientific quest for life's origin. Washington: Joseph Henry; 2005.

Kutschera U. Intelligent design creationism versus modern biology: no middle way. In: Parker MG, Schmidt TM, editors. Scientific explanation and religious belief. Tübingen: Mohr Siebeck; 2005. p. $150-64$.

Kutschera U. A timely wake-up call as anti-evolutionists publicize their views. Nature. 2006a;444:679.

Kutschera U. The basic types of life: critical evaluation of a hybrid model. Rep Natl Cent Sci Edu. 2006b;26:31-6.

Kutschera U. Darwin 200: great expectations. Nature. 2008a;456:318.

Kutschera U. From Darwinism to evolutionary biology. Science. 2008b;321:1157-8.

Kutschera U. Symbiogenesis, natural selection, and the dynamic Earth. Theory Biosci. 2009. doi:10.1007/s12064-009-0065-0.

Kutschera U, Niklas KJ. The modern theory of biological evolution: an expanded synthesis. Naturwissenschaften. 2004;91:255-76.

Numbers RL. The creationists: from scientific creationism to intelligent design. Cambridge: Harvard University Press; 2006.

Paley W. Natural theology: or, evidences of the existence and attributes of the Deity, collected from the appearances of nature. 5th ed. London: Fauldner; 1803.

Peckham M. The origin of species by Charles Darwin. A variorum text. Philadelphia: University of Pennsylvania Press; 1959.

Schönborn C. Finding design in nature. The New York Times 2005; 7. July.

Scott EC. Evolution vs. creationism: an introduction. Berkeley: University of California Press; 2005.

Scott EC, Branch G. Don't call it "Darwinism”. Evo Edu Outreach. 2009;2:90-4.

Seward AC (ed.) Darwin and modern science. Essays in commemoration of the centenary of the birth of Charles Darwin and the fiftieth anniversary of the publication of The Origin of Species. Cambridge: Cambridge University Press; 1909. 